\title{
Diamond fraud analysis in detecting financial statement fraud
}

\author{
Rani Eka Diansari, Arum Tri Wijaya \\ Universitas PGRI Yogyakarta \\ ranieka@upy.ac.id, arum_triwijaya@yahoo.co.id
}

\begin{abstract}
This study aims to analyze the influence of variable pressure proxied by financial stability, personal financial need, financial targets, external pressure, the opportunity proxied by nature of the industry, ineffective monitoring, rationalization, and capability of the financial statement fraud. The sample used 72 manufactured company listing on the Indonesia Stock Exchange during the 2014-2017 period. Multiple linear regression test is used to test the influence of the independent variable on the dependent variable. The result showed that financial stability, the ratio of the change in total assets, and external pressure, as measured by leverage, showed an influence on financial statement fraud while the personal financial need, financial targets, nature of industry, ineffective monitoring, rationalization, and capability does not influence financial statement fraud.
\end{abstract}

Keywords: Fraud diamond; fraud triangle; financial statement fraud

\section{Background}

The company's financial statement is used as a communication tool for the highest managers to their employees and external parties of the company to report the company's activities in a certain period (Ratmono, Diany, \& Purwanto, 2014). The financial statement provides an overview of accounting information that connects the company's economic activities and the user of financial statements (Pangesty, Nuraina, \& Sulistyowati, 2018). Information provided by the source of information to financial statement users must be free from fraud, relevant, and accurate to avoid misleading in making a decision (Sari, DP, \& Rusli, 2016). One of the references that are used by business people is financial statements, but due to competition, some people might manipulate financial statements. Ignoring the number and misstatement that been done intentionally with a purpose to deceive the users of the report is the definition of financial statement fraud (Darmawan, 2016).

The world was shocked by the disclosure of the financial statement manipulation scandal involving energy company Enron and Arthur Andersen Public Accountant Firm by recording a USD 600,000,000 as profit when the company suffered a loss in 2002 (Indriani, 2017). Cases of fraud in Indonesia, one of which was at PT Indofarma, which was found a misstated (Rahmayuni, 2018). The Association of Certified Fraud Examiners (ACFE) in the Report to the Nations on Occupational Fraud and Abuse-Asia Pacific Edition found 13\% of fraud committed on the financial statements, as well as $80 \%$ misappropriation of assets with losses found reach $\$ 700,000$ higher than the asset misuse that reaches $\$ 180,000$ (ACFE, 2018). The manufacturing sector becomes the first rank in doing the fraud that reaches 38 cases and a loss of $\$ 500,000$ (ACFE, 2018). Fraud can occur when detection and prevention efforts are not made properly. There are several ways to detect fraud, one of which is a fraud triangle (Annisya \& Asmaranti, 2016). 
Donald Cressey (1953) concluded that there are three conditions for committing fraud; those are pressure, opportunity, and rationalization, which called the fraud triangle (Skousen, Smith, \& Wright, 2009). Wolfe et al. (2004: 38) in (Annisya \& Asmaranti, 2016) introduced a new model called "fraud diamond" by adding a capability element. This study develops previous research, namely Annisya, Asmaranti (2016), about the detection of financial statement fraud using fraud diamonds. Previous research has inconsistent results. Herdiana \& Sari (2018) showed that external pressure does not significantly affect financial reporting fraud. While Septriani \& Handayani's (2018), Faradiza \& Suyanto (2017) stated that external pressure affected financial reporting fraud. This study is interesting because the sample used is a manufacturing company in which the sector has the highest fraud case (ACFE, 2018).

\section{Theoretical Background}

\subsection{Agency Theory}

Agency theory is a concept that explains the contractual relationship between an agent and the principal. Principals are those who give the mandate to the agent who responded to make a decision (Jensen \& Meckling, 1976). When management has an interest in maximizing its welfare, agents tend not to act following the principal's affairs. This will cause the information provided by the agent might mislead the stakeholders (Annisya \& Asmaranti, 2016). This difference in interests causes a conflict of interest between the two parties, which causes the agent to face pressure (pressure) to find ways to improve performance so that the agent gets appreciation from the principal (rationalization). The opportunity to commit fraud will be even more excellent if management has broad access (capability) and opportunities to increase profits (opportunity) (Sihombing \& Rahardjo, 2014).

\subsection{Fraud}

Statement of Auditing Standards (SAS) No. 99 defines fraud as a deliberate act that causes material misstatement in financial statements that become subject to an audit. There are three types of fraud based on actions, namely:

a. Asset diversion is misuse by stealing the assets of an organization or another party.

b. A false statement that is the presentation of financial statements made by an official of the organization to conceal the right financial condition by doing manipulation to get some profit.

Corruption is fraud committed by abusing authority or conflicts of interest, illegal revenue, financial extortion, and bribery. Corruption is the most challenging type of fraud to detect because it relates to parties who work together to gain profit

\subsection{Financial Statement Fraud}

Financial Statement Fraud attempts to present financial statements that are not by generalthemed accounting principles. Intentions are material, so that might influence those who make the decision (Herdiana \& Sari, 2018). There are two types of deliberate misinformation in the financial statements for fraud under SAS No.99, namely: 
a. Fraudulent financial reporting

Fraudulent financial reporting is intentional misstatement or negligence in the disclosure of financial statements intended to harm the users of financial statements.

b. Misappropriation of assets

Misappropriation of assets is the misuse of assets that done in several ways such as asset thievery which make the organization has to pay for assets that are not received.

\subsection{Fraud Triangle Theory}

Fraud Triangle Theory is an idea that examines the factors causing fraud. This idea was found by Cressey in 1953 (Sari et al., 2016). Fraud triangle illustrates three factors that cause fraud:

a. Pressure

The pressure is the motivation of an individual to fraud due to financial or nonfinancial pressure from individuals and organizations (Rahmayuni, 2018). There are four general conditions happen to pressure that can lead to fraud, namely financial stability, external pressure, personal financial needs and financial targets (Rahmanti, 2013).

b. Opportunity

Opportunities for fraud can occur related to an environment where fraud makes it possible to carry out internal controls, lack of management supervision, and unclear procedures that open opportunities for fraud (Sukirman \& Sari, 2013). There are three categories of conditions on the opportunity that can lead to fraud, namely the nature of the industry, ineffective monitoring and organizational structure (AICPA, 2002).

c. Rationalization

Rationalization is an attitude, character, or set of ethical values that allow management or employees to commit fraud (Elder et al., 2011 in (Sari et al., 2016)). Two conditions might cause a fraud; those are auditor change and audit opinion (Skousen et al., 2009)

\subsection{Fraud Diamond Theory}

This theory was introduced by Wolfe \& Hermason in (2004), by adding an element of the capability to detect fraud in financial statements. Capacity is a trait or ability to play a role when fraud occurs. According to (Wolfe \& Hermanson, 2004) there are five attitudes of perpetrators of fraud, namely:

a. People who have important positions in the company

b. People who understand the weaknesses of internal control of a company

c. People who have a high level of self-confidence and ego

d. People who have the personality to convince others to commit fraud in the company

e. People who commit fraud consistently and successful.

Fraud that has a sizeable nominal value occurs if there are unique capabilities contained in the organization. The first study by Dechow, et al., the F-Score Model, is designed, tested, and proven to be an accurate indicator of fraudulent material financial 
statements. The F-Score Model is a sum of accrual quality and financial performance (Skousen et al., 2009).

\section{Hypothesis Development}

\section{The effect of financial stability on fraudulent financial statements}

Financial stability is a stable financial condition in a company, which can be influenced by a country's economic situation. If a country's financial condition is unstable, it can affect the company's financial stability. This can lead to fraud because management will try to display a remarkable financial statement (Aprilia, 2017). Financial stability can help auditors to detect financial statement fraud. If the total assets decreased, then management can be motivated to do profit management (Windarti, 2015). Based on the description above, the hypotheses that can be formulated are as follows:

\section{$H_{1}$ : Financial stability has a negative effect on financial statement fraud}

\section{The influence of personal financial need on financial statement fraud}

Beasley (1996) and Dunn (2004) in (Skousen et al., 2009) indicate that when executives have a significant stake in the company, they will personally feel threatened by the company's performance. Research conducted by Skousen (2009) shows that personal financial need has a positive effect on fraud in financial statements. Based on the description above, the hypotheses that can be submitted are as follows:

$\mathrm{H}_{2}$ : Personal financial need has a positive effect on financial statement fraud

\section{The influence of external pressure on financial statement fraud}

External pressure is excessive pressure for management to meet the requirements or expectations of third parties (Tiffani \& Marfuah, 2015). The pressure experienced by company management is the need for additional debt and external financing sources to remain competitive such as the development of factories and facilities (Skousen et al., 2009). Research conducted by Sari (2016) showed that external pressure influences financial statement fraud. Based on the description above, the hypothesis proposed is as follows:

\section{$H_{3}$ : External pressure has a positive effect on financial statement fraud}

\section{The effect of financial targets on financial statement fraud}

Company managers are required to give the best performance so they can achieve the financial targets that have been budgeted. Return of Assets is a measure of operational performance that can be used to show the efficiency of the assets used (Skousen et al., 2009). The higher the ROA targeted, the higher the possibilities of management committed to a fraud (Tiffani \& Marfuah, 2015). Based on the description above, the formulation of the proposed hypothesis is as follows:

\section{$\mathrm{H}_{4}$ : Financial targets have a positive effect on financial statement fraud}




\section{The effect of nature of industry on financial statement fraud}

The nature of the industry is the ideal state of the industry in a company where certain financial items have a balance whose amount is determined by the company based on estimates, for example, uncollectible receivables and obsolete inventory (Tiffani \& Marfuah, 2015). Research by Summers and Sweeney (1998) in Herdiana (2018) shows that the ratio of changes in accounts receivable has a positive effect on financial statement fraud. Based on the description above, the formulation of the proposed hypothesis is as follow:

$H_{5}$ : Nature of industry has a positive effect on financial statement fraud

\section{The effect of effective monitoring on financial statement fraud}

Fraud can be minimized by good oversight mechanisms. The audit committee is believed to be able to increase the effectiveness of company supervision (Tiffani \& Marfuah, 2015). Effective internal control can maintain the reliability of reports that prevent fraud. Weak internal audits can increase the likelihood of material misstatement (Lou \& Wang, 2009). Based on the description above, the hypothesis proposed is as follows:

\section{$H_{6}$ : Effective monitoring has a positive effect on financial statement fraud}

\section{The effect of rationalization on financial statement fraud}

Rationalization is an important element in the occurrence of fraud which causes the perpetrators of fraud to seek justification for their actions (Sari et al., 2016). Research conducted (Skousen et al., 2009) showed that rationalization measured by auditor turnover. A company can replace the auditor to reduce the possibility of detecting fraudulent financial statements by the auditor (Lou \& Wang, 2009). Based on the above description of the hypothesis put forward as follows:

\section{$H_{7}$ : Rationalization has a positive effect on financial statement fraud}

\section{The effect of capability on fraudulent financial statements}

Capability is an attempt by someone to commit fraud in order to achieve certain goals (Annisya \& Asmaranti, 2016). Changes in directors as a proxy of capability to find out the occurrence of fraudulent financial statements because when changes in directors can lead to an initial performance that is not optimal because in the period of adaptation (Sihombing \& Rahardjo, 2014). Based on the description above, the hypothesis proposed is as follows:

$H_{8}$ : Changes in directors have a positive effect on financial statement fraud.

\section{Research Method}

The object of this research is a company engaged in the manufacturing sector which was listed on the Indonesia Stock Exchange in 2014-2017. The sample data in this study were 72 companies that met the research criteria. The data used in this research are data relating to the calculation of research variables contained in the annual reports of manufacturing companies listed on the Indonesia Stock Exchange in 2014-2017. The sampling criteria are:

a. Manufacturing companies listed on the Indonesia Stock Exchange for the period 2014-2017. 
b. Companies that publish annual financial reports on the IDX website or company website during the period 2014-2017 expressed in rupiah.

c. Companies that publish data relating to research variables in full.

d. Companies that were not delisted during the study period.

e. Companies that have audited reports during the study period.

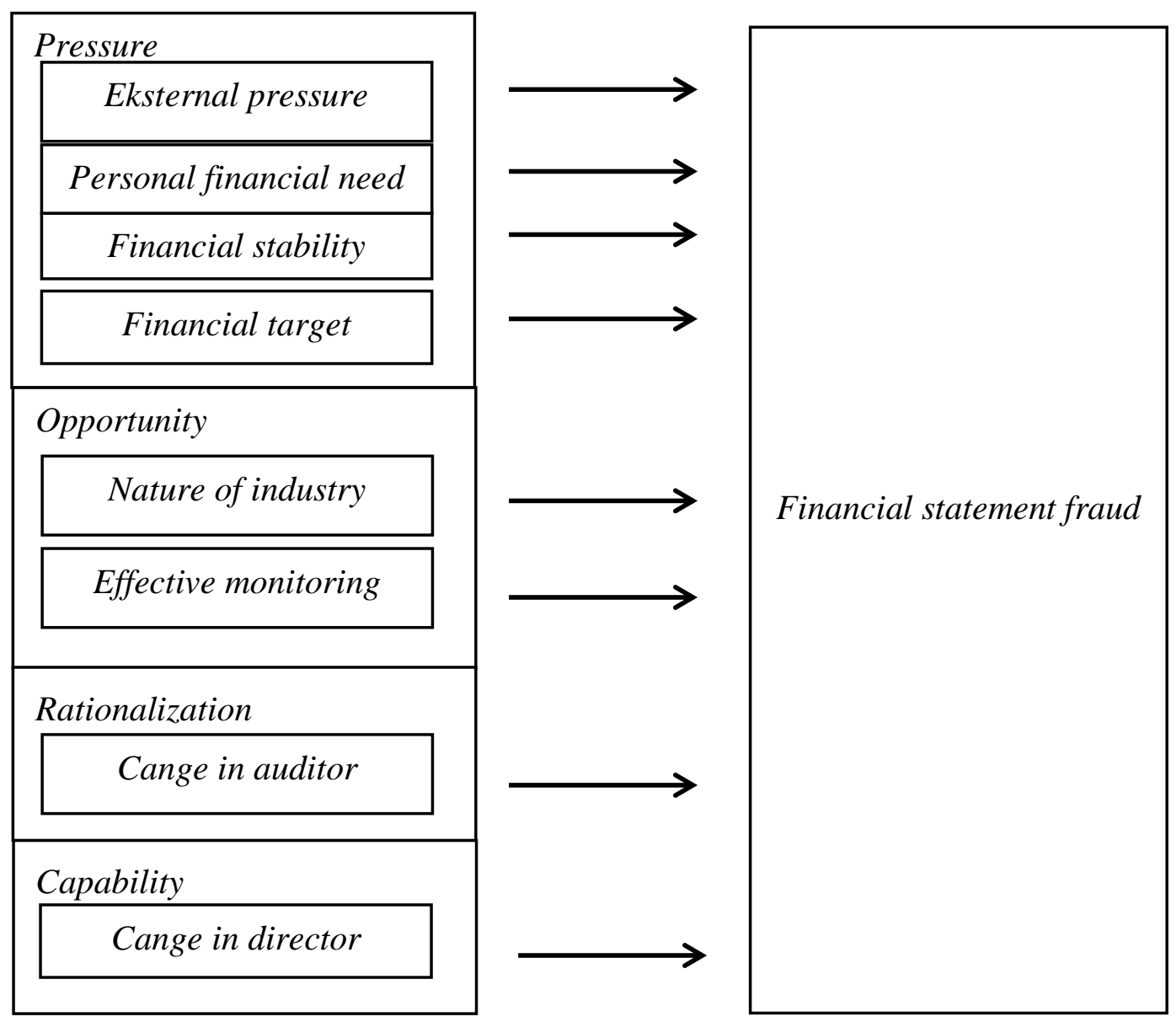

Figure 1. Research Model

The following details regarding the selection of research samples:

Table 1. Sampling Selection Summary

\begin{tabular}{clc}
\hline No. & Criteria of Company & Total \\
\hline 1 & $\begin{array}{l}\text { Companies engaged in the manufacturing sector were listed on the } \\
\text { Indonesia Stock Exchange in 2014-2017. }\end{array}$ & 128 \\
2 & $\begin{array}{l}\text { Companies that publish data relating to research variables are sourced } \\
\text { from fully annual reports. }\end{array}$ & $(41)$ \\
3 & $\begin{array}{l}\text { Companies that present annual financial statements in rupiah. } \\
4\end{array}$ & Number of company samples used in the study \\
\hline
\end{tabular}

The type of data used in this study is secondary data. Secondary data is data that does not directly provide information to data collectors through documents or other people. The secondary data in this study are the annual financial statements of manufacturing companies in the 2013-2014 period, which are accessed through the Indonesia Stock Exchange website, namely www.idx.co.id and the company's official website. 
The dependent variable in this research is financial statement fraud which is measured using a fraud score model in the form of the sum of two variables, namely accrual quality and financial performance (Skousen \& Twedt, 2009), which can be formulated as follows:

\section{F-Score = Accrual Quality + Financial Performance}

Accrual quality is defined as changes in non-cash and non-equity in a company's balance sheet. Accrual quality is calculated by RSST accrual (Dechow in (Skousen et al., 2009)) with the following formula:

RSST Accrual $=\frac{(\triangle \mathrm{WC}+\Delta \mathrm{NCO}+\triangle \mathrm{FIN})}{\text { Average Total Aset }}$

\footnotetext{
Explanations:

$\mathrm{WC}($ working capital $)=($ Current Assets - Current Lialility $)$

NCO (Non Current Operating Accrual $)=($ Total Assets - Current Assets - Invesment and Advances) - (Total Liabilities-Current Liabilities - Long Term Debt)

FIN $($ Financial Accrual $)=$ Total Investment - Total Liabilitie

ATS $($ Average Total Assets $)=($ Beginning Total Assets + End Total Assets $): 2$
}

Financial performance of a company's financial statements is considered capable of predicting financial statement fraud (Skousen \& Twedt, 2009). Financial performance can be related to changes in accounts receivable, inventory, cash sales and earnings with the following formula:

Financial performance $=$ change in receivable + change in inventories + change in cash sales + change in earnings

Explanations:

\begin{tabular}{|c|}
\hline $\begin{aligned} \text { Change in Receivables }= & \Delta \text { receivables } \\
& \text { Average total assets }\end{aligned}$ \\
\hline Change in inventories $=\frac{\triangle_{\text {inventories }}}{\text { Average total assets }}$ \\
\hline Change in cash sales $=\triangle_{\text {Sales }(t)}-\triangle_{\text {sales }}^{\text {receivable }}$ \\
\hline $\begin{array}{c}\text { Change in earnings }=\text { earnings }(t) \\
\text { Average total assets }(t)\end{array}-\frac{\text { earnings }(t-1)}{\text { Average total assest }(t-1)}$ \\
\hline
\end{tabular}

The independent variables of the study are as follows:

a. Financial stability

Financial stability is a condition that reflects the company's stable financial condition (Herdiana \& Sari, 2018). The higher ratio of changes in the total assets of a company, the 
higher possibility of fraud will be. The variable financial stability of the study is proxied by the ratio of changes in total assets (ACHANGE), with the formula (Skousen et al., 2009) as follows:

$$
\text { ACHANGE }=\frac{\text { Total Aset }{ }_{t}-\text { Total Aset }_{\mathrm{t}-1}}{\text { Total Aset }_{\mathrm{t}-1}}
$$

b. Personal financial need

Personal financial need is a company's financial condition that is influenced by financial conditions of company executives (Skousen et al., 2009). Financial conditions are affected by the shareholding of managers, directors, or board of commissioners of the company. Personal financial need is proxied by ownership of shares by company officials with the formula (Skousen et al., 2009):

$$
\text { OSHIP }=\frac{\text { Shareholder by owner }}{\text { Total shareholder }}
$$

c. External pressure

External pressure is the excessive pressure for management to meet the expectations or requirements of third parties (Annisya \& Asmaranti, 2016). The external pressure variable is proxied by the leverage ratio calculated by the formula debt to total assets (Skousen et al., 2009) as follows:

$$
\mathrm{LEV}=\frac{\text { Total Debt }}{\text { Total Assets }}
$$

\section{d. Financial Targets}

Financial targets are the excessive pressure on management to achieve the financial targets set by directors or management. Company managers are required to manage the targets that have been set to be achieved (Wahyuni \& Budiwitjaksono, 2017). Financial targets are proxied by ROA (Kasmir, 2018) which is calculated using the formula presented in the following formula:

$$
\mathrm{ROA}=\frac{\text { Earnings after interest and tax }}{\text { Total assets }}
$$

e. Nature of Industry

Nature of industry is an ideal state of a company in the industry (Annisya \& Asmaranti, 2016). The balance in a particular account is determined largely based on estimates and 
subjective judgments (Skousen et al., 2009). Accounts receivable and inventory require subjective judgment in estimating uncollectible receivables Summers \& Sweeney, 1998 in (Skousen et al., 2009). Therefore, this study uses a proxy for the ratio of total receivables with the following formula:

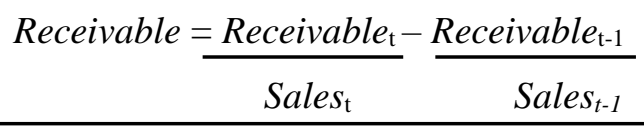

f. Effective Monitoring

Companies that commit fraud consistently have fewer members of the board of directors than companies who do not commit fraud (Skousen et al., 2009). Therefore, ineffective monitoring is proxied by BDOUT with the formula (Skousen et al., 2009) as follows:

$\mathrm{BDOUT}=$ The Amount of independent board of commissioners

Total board of commissioners

g. Rationalization

Research shows that auditor failure and litigation increase after companies replace auditor Stice 1991 in (Skousen et al., 2009). Then in the research, rationalization is proxied by the change of auditors measured by dummy variables. If the company changes the auditor during the 2014-2017 period, it is given code 1, and if the company does not change the auditor, it is given code 0 (Sihombing \& Rahardjo, 2014).

h. Capability

Changes in the board of directors can cause a stress period which results in greater opportunities for fraud. This research using DCHANGE or company directors turnover as a proxy for capabilty. Change of directors is measured by the dumm variable. Companies that change directors during the 2014-2017 period are given code 1, and companies that do not change directors are given code 0 (Annisya \& Asmaranti, 2016).

\section{Results And Discussion}

Table 2. Result of Statistic Descriptive Test

\begin{tabular}{llcccc}
\hline Variable & N & \multicolumn{1}{c}{ Minimum } & Maximum & \multicolumn{1}{c}{ Mean } & Std. Dev. \\
\hline ACHANGE & 275 & $-0,69$ & 0,50 & 0,06 & 0,13 \\
OSHIP & 275 & 0,00 & 0,84 & 0,05 & 0,13 \\
LEV & 275 & 0,04 & 2,06 & 0,46 & 0,26 \\
ROA & 275 & $-0,21$ & 0,39 & 0,04 & 0,08 \\
REV & 275 & $-0,69$ & 0,59 & 0,00 & 0,08 \\
BDOUT & 275 & 0,25 & 0,80 & 0,38 & 0,10 \\
AUCHANGE & 275 & 0 & 1 & 0,14 & 0,34 \\
DCHANGE & 275 & 0 & 1 & 0,41 & 0,49 \\
FRAUD & 275 & $-3,47$ & 3,48 & 0,29 & 0,54 \\
\hline
\end{tabular}


The results of descriptive statistics can be seen in the following table 2. This research has conducted the classical assumption test stages those are: normality test, multicollinearity test, heterokedasticity test and autocorrelation test. In the table 3. is the result of multiple linear analysis testing, to find out how much the independent variable affect the dependent variable.

Table 3. Regression Testing

\begin{tabular}{crrr}
\hline Variable & $\boldsymbol{\beta}$ & $\mathbf{t}$ & \multicolumn{1}{c}{ Sig. } \\
\hline Constant & 0,456 & 3,324 & $0,001^{*}$ \\
ACHANGE & $-0,621$ & $-2,505$ & $0,013^{*}$ \\
OSHIP & $-0,013$ & $-0,052$ & 0,959 \\
LEV & 0,273 & 2,025 & $0,044^{*}$ \\
ROA & $-0,478$ & $-1,152$ & 0,251 \\
RECEIVABLE & 0,339 & 0,897 & 0,370 \\
BDOUT & $-0,482$ & $-1,520$ & 0,130 \\
AUCHANGE & $-0,175$ & $-1,873$ & 0,062 \\
DCHANGE & $-0,041$ & $-0,619$ & 0,536 \\
\hline Adj $R^{2}=0,053$ & & & $0,004^{*}$ \\
F $=2,8990$ & & & \\
\hline Sig $<5 \%$ & & & \\
\hline
\end{tabular}

$*$ Sig $<5 \%$

Hypothesis testing used multiple linear analysis to test the effect of financial stability (ACHANGE), personal financial need (OSHIP), external pressure (LEV), financial targets (ROA), nature of industry (REV), ineffective monitoring (BDOUT), rationalizatiom (AUCHANGE) ), and capability (DCHANGE) against financial statement fraud is calculated using the following formula:

FRD $=0,456-0,621$ ACHANGE - 0,013 OSHIP + 0,273 LEV - 0,478 ROA + 0,339 REV 0,482 BDOUT - 0,175 AUCHANGE - 0,041 DCHANGE + e

The coefficient of determination (Adjusted R Square) test showed a value of 0.053. It shows that $5.3 \%$ of financial statement fraud is influenced by the independent variables in this study. While the remaining $94.7 \%$ is influenced by other variables not included in the regression model of this study.

Simultaneous test ( $F$ test) in this study showed a significant value of 0.004 . Significance value that is smaller than 0.05 , showed the regression model can predict financial statement fraud and independent variables together affect the dependent variable.

The variable Financial stability (ACHANGE) has a negative effect on financial statement fraud, because it has a significance value $<0.05$ with a coefficient value of -0.662 , which means that financial stability has a negative effect on financial statement fraud. These results support Widarti's previous research (2015) which suggested that financial stability can help auditors to detect fraud in financial statements. It showed that the declining financial stability of a company could increase fraudulent financial statements. The negative coefficient value might be caused by a decrease in the total assets of the company. When changes in total assets decline, it can trigger management to manage profit so that the performance and growth of the company have increased (Windarti, 2015). Company assets are used to describe the company's financial condition. Unstable company conditions might 
be caused by management performance that is less able to maximize assets, causing changes in assets that are too high or too low (Annisya \& Asmaranti, 2016).

Variable Personal financial need (OSHIP) has no effect on financial statement fraud, because the significance value is greater than 0.05 with a coefficient value of -0.013 . The results of this analysis support Rahmanti's research, 2013 which states that managers who own insignificant shares will further increase their profits through bonuses received.

The leverage variable has a positive effect on financial statement fraud, because of the significance value $<0.05$ with a coefficient value of 0.273 . The results of the analysis are supported by research conducted by Tiffani and Marfuah (2015), Sihombing and Rahardjo (2014) and Listyaningrum, et al., (2017) shows that leverage has a positive effect on financial statement fraud. Greater leverage can be attributed to a higher tendency to breach credit agreements. Lower ability to obtain loans (Listyaningrum, Paramita, \& Oemar, 2017). External pressure in the form of high credit risk caused by loans or high debt to creditors can cause company managers to manipulate financial statements (Annisya \& Asmaranti, 2016).

Financial targets variable as measured by return on assets (ROA) does not affect the financial statement fraud, because the significance value $>0.05$ with a coefficient value of 0.478. The results of the analysis are supported by research conducted by Annisya et al. (2016), Sihombing and Rahardjo (2014) and Arfiyadi and Indah (2016) showed that ROA has no effect on financial statement fraud. The company's ROA value rises, so the company is able to generate profits from its assets. Asset investment funds come from the sale of shares, because basically the stock price is related to the company's financial condition. High company earnings, investor confidence will increase so that share prices are also high. High stock prices will result in increased dividend payments, so company management does not commit financial statement fraud (Wahyuni \& Budiwitjaksono, 2017). In addition, the selection of human resources, company policies such as marketing management, accounting methods used can also increase the value of the company (Annisya \& Asmaranti, 2016).

Receivable variable (REV) has a not significant-positive effect on financial statement fraud, because the significance value $>0.05$ with a coefficient value of 0.339 . The results of the study are supported by research by Faradiza and Suyanto, (2017) which states that the increase in the number of receivables the previous year was unable to indicate that the company's cash turnover was not good. A low average level of receivables indicates that the company suppresses the amount of receivables and increases the amount of cash receipts. Corporate receivables are under controlled conditions and smooth cash receipts reduce the tendency of companies to commit fraudulent financial statements (Oktarigusta, 2017).

BDOUT as a variable does not affect financial statement fraud, because the significance value $>0.05$ with a coefficient value of -0.482 . The results of the study were supported by previous research, conducted by Maria Ulfah, et al. (2017), Sihombing and Rahardjo (2014), Rahmanti, et al., (2013) who stated ineffective monitoring had no significant effect on financial statement fraud. More and more independent commissioners are expected to be able to improve company performance, but it will be different if there are interventions that result in the objectivity of supervision (Hanafi, 2017). The number of independent directors has no effect on fraud on the financial statements because the number of the board of commissioners has been regulated in the Decree of the Chairman of Bapepam 
LK Number: Kep-643 / BL / 2012 concerning the Establishment and Guidelines for the Audit Committee's Work Implementation.

AUCHANGE variable has no effect on financial statement fraud, because the significance value $>0.05$ with a coefficient value of -0.175 . The results of the study are supported by Sihombing and Rahardjo's (2014) research which states that changes in auditors have no effect on financial statement fraud. Auditors are supervisors who are qualified in auditing the company's financial statements. There are more companies that do not change auditors than companies that change auditors. Change of auditors is carried out by the company to comply with applicable regulations, so the company decides to appoint a new auditor to provide audit services (Rahmayuni, 2018).

The DCHANGE variable has no effect on financial statement fraud, because the significance value> 0.05 with a coefficient value of -0.041 . The results of the study were supported by research conducted by Annisya et al (2016) and Sihombing and Rahardjo (2014) who stated that changes in directors had no effect on financial statement fraud. Research results indicate the level of change of directors does not affect financial statement fraud. Changes in directors can be caused by resignation or the board of directors dies so that requires new members of the board of directors. Changes in directors can also be caused by companies making performance improvements by recruiting more competent directors (Nugraheni \& Triatmoko, 2018).

\section{Conclusion and Suggestion}

Based on research conducted on 72 companies in manufacturing sector in the 2015-2017 period, the conclusions are Financial stability and external pressure have a significant effect on financial statement fraud. Personal financial need, financial targets, nature of industry, effective monitoring, rationalization and capability does not affect financial statement fraud. This study has several limitations such as the use of f-scores to measure financial statement fraud. Moreover, fraud can be measured by the Beneish M-Score model which can indicate a drastic increase in receivables, agravate gross margins, and an increase in accruals (Beneish, 1999). Future studies are expected to include other factors of rationalization and capability variables such as audit opinion without exception because it allows management to be rationalization so as to provide tolerance for management in managing earnings (Annisya \& Asmaranti, 2016).

\section{REFERENCES}

ACFE. (2018). Report to Nation. Retrieved from https://www.acfe.com/report-to-thenations/2018/

Annisya, M., \& Asmaranti, Y. (2016). Pendeteksian Kecurang Laporan Keuangan Menggunakan Fraud Diamond. Jurnal Bisnis dan Ekonomi, 23(1).

Aprilia. (2017). Analisis Pengaruh Fraud Pentagon terhadap Kecurangan Laporan Keuangan Menggunakan Beneish Model pada Perusahaan yang Menerapkan Asean Corporate Governance Scorecard. Jurnal Aset (Akuntansi Riset), 9(1), 101-132.

Beneish, M. D. (1999). The Detection of Earnings Manipulation. Financial Analysts Journal, 55(5), 12. 
Darmawan, A. Z. (2016). Analisis Beneish Ratio Index untuk Mendeteksi Kecurangan Laporan Keuangan. Jurnal Profita: Kajian Ilmu Akuntansi, 4(6).

Hanafi, Z. N. R. (2017). Analisi Pengaruh Fraud Diamond dalam Mendeteksi Irregularities. Jurnal Akuntansi Indonesia, 6(2), 15.

Herdiana, R., \& Sari, S. P. (2018). Analisis Fraud Diamond dalam Mendeteksi Financial Statement Fraud (Studi Empiris Perusahaan Manufaktur yang Terdaftar di Bursa Efek Indonesia Periode 2015-2017). Paper presented at the Seminar Nasional dan Call For Paper Iii Fakultas Ekonomi.

Indriani, P. (2017). Fraund Diamond dalam Mendeteksi Kecurangan Laporan Keuangan. IFinance: a Research Journal on Islamic Finance, 3(2), 161-172-161-172.

Jensen, M. C., \& Meckling, W. H. (1976). Theory of the firm: Managerial behavior, agency costs and ownership structure. Journal of financial economics, 3(4), 305-360.

Kasmir. (2018). Analisis Laporan Keuangan PT Raja Grafindo Persada. Jakarta.

Listyaningrum, D., Paramita, P. D., \& Oemar, A. (2017). Pengaruh Financial Stability, External Pressure, Financial Target, Ineffective Monitoring dan Rasionalisasi Terhadap Kecurangan Pelaporan Keuangan (Fraud) Pada Perusahaan Manufaktur di Bei Tahun 2012-2015. Journal Of Accounting, 3(3).

Lou, Y.-I., \& Wang, M.-L. (2009). Fraud risk factor of the fraud triangle assessing the likelihood of fraudulent financial reporting. Journal of Business \& Economics Research (JBER), 7(2).

Nugraheni, N. K., \& Triatmoko, H. (2018). Analisis Faktor-Faktor yang Mempengaruhi Terjadinya Financial Statement Fraud: Perspektif Diamond Fraud Theory (Studi Pada Perusahaan Perbankan Yang Terdaftar di Bursa Efek Indonesia Periode 20142016). Jurnal Akuntansi dan Auditing, 14(2), 118-143.

Oktarigusta, L. (2017). Analisis Fraud Diamond Untuk Mendeteksi Terjadinya Financial Statement Fraud Di Perusahaan (Studi Empiris pada Perusahaan Manufaktur yang Terdaftar di BEI Tahun 2012-2015). Jurnal Manajemen Dayasaing, 19(2), 93-108.

Pangesty, S. S., Nuraina, E., \& Sulistyowati, N. W. (2018). Pengaruh Fraud Diamond terhadap Deteksi Kecurangan Laporan Keuangan pada Perusahaan Manufaktur yang Terdaftar di BEI. Paper presented at the FIPA: Forum Ilmiah Pendidikan Akuntansi.

Rahmanti, M. M. (2013). Pendeteksian Kecurangan Laporan Keuangan Melalui Faktor Risiko Tekanan dan Peluang (Studi Kasus pada Perusahaan yang mendapat Sanksi dari Bapepam Periode 2002-2006). Diponegoro Journal Of Accounting, 2(2), 1-12.

Rahmayuni, S. (2018). Analisis Pengaruh Fraud Diamond terhadap Kecurangan Laporan Keuangan (Studi Empiris pada Perusahaan Manufaktur yang Terdaftar di BEI Tahun 2013-2016). Jurnal Akuntansi, 6(1).

Ratmono, D., Diany, Y. A., \& Purwanto, A. (2014). Dapatkah Teori Fraud Triangle Menjelaskan Kecurangan dalam Laporan Keuangan? Jurnal Akuntansi dan Auditing, 14(2), 100-117.

Sari, S. T., DP, E. N., \& Rusli, R. (2016). Pengaruh Financial Stability, External Pressure, Financial Targets, Ineffective Monitoring, Rationalization pada Financial Statement Fraud dengan Perspektif Fraud Triangle (Studi Empiris pada Perusahaan Perbankan Periode 2012-2014 yang Terdaftar di Bursa. Jurnal Online Mahasiswa Fakultas Ekonomi Universitas Riau, 3(1), 664-678.

Sihombing, K. S., \& Rahardjo, S. N. (2014). Analisis fraud diamond dalam mendeteksi financial statement fraud: studi empiris pada perusahaan manufaktur yang terdaftar di Bursa Efek Indonesia (BEI) Tahun 2010-2012. Diponegoro Journal of Accounting, 3(2), 1-12. 
Skousen, C. J., Smith, K. R., \& Wright, C. J. (2009). Detecting and predicting financial statement fraud: The effectiveness of the fraud triangle and SAS No. 99. In Corporate governance and firm performance (pp. 53-81): Emerald Group Publishing Limited.

Skousen, C. J., \& Twedt, B. J. (2009). Fraud score analysis in emerging markets. Cross Cultural Management: An International Journal, 16(3), 301-316.

Sukirman, S., \& Sari, M. P. (2013). Model deteksi kecurangan berbasis fraud triangle. Jurnal Akuntansi dan Auditing, 9(2), 199-225.

Tiffani, L., \& Marfuah, M. (2015). Deteksi financial statement fraud dengan analisis fraud triangle pada perusahaan manufaktur yang terdaftar di bursa efek Indonesia. Indonesian Journal of Accounting and Auditing, 19(2), 112-125.

Wahyuni, W., \& Budiwitjaksono, G. S. (2017). Fraud triangle sebagai pendeteksi kecurangan laporan keuangan. Jurnal Akuntansi, 21(1), 47-61.

Windarti. (2015). Pengaruh Fraud Triangle terhadap Deteksi Kecurangan Laporan Keuangan pada perusahaan Manufaktur yang Terdaftar di Bursa Efek Indonesia Jurnal Manajemen dan Bisnis, 13 (2), 16.

Wolfe, D. T., \& Hermanson, D. R. (2004). The fraud diamond: Considering the four elements of fraud. 